

International Conference on Renewable Energies and Power Quality (ICREPQ'18)

Salamanca (Spain), $21^{\text {th }}$ to $23^{\text {th }}$ March, 2018

Renewable Energy and $\mathscr{P}_{\text {ower }} Q_{\text {uality }}$ Sownal (RE\&PQJ)

ISSN 2172-038 X, No.16 April 2018

\title{
Potential benefits of distributed generation in the reduction of non-technical losses
}

\author{
Eduardo Baffi ${ }^{1}$, Rafael Martin Lamaison Urioste ${ }^{2}$ and Mònica Aragüés Peñalba ${ }^{3}$ \\ ${ }^{1}$ Ministry of Transparency and Comptroller-General (CGU) \\ SAS Quadra 1 Bloco A, Edifício Darcy Ribeiro, Brasília/DF 70.070-905 (Brazil) \\ Phone number: +0055 9993 1707, e-mail: edubaffi@gmail.com \\ ${ }^{2}$ Electronic Engineering Department \\ ETSEIB, Polytechnic University of Catalonia (UPC) \\ Edifici H, planta 9, Avda. Diagonal, 64708028 Barcelona (Spain) \\ Phone number: +0034 93 4010947, e-mail: rafael.martin.lamaison@upc.edu \\ ${ }^{3}$ Electrical Engineering Department \\ ETSEIB, Polytechnic University of Catalonia (UPC) \\ Edifici H, planta 2, Avda. Diagonal, 64708028 Barcelona (Spain) \\ Phone number: +0034 93 4054245, e-mail: monica.aragues@ citcea.upc.edu
}

\begin{abstract}
Power generation at or near the consumers can affect citizens positively, especially those who belong to social classes with low earnings. This article proposes an analysis of potential economic and technical benefits that the insertion of Distributed Generation (DG) in low-income communities can create, including the reduction of commercial losses, and alternatives to allow viable financing.
\end{abstract}

\section{Key words}

Distributed generation, non-technical losses, technical benefit, economic benefit, low-income citizens.

\section{Introduction}

There are more than 207.2 million people living in Brazil and they are irregularly distributed in around 8,516,000 $\mathrm{km} 2$. Although more than $99 \%$ of the Brazilians have electricity supply, in 2010 more than 2.7 million did not have access to this essential public service, including almost 400 thousand in cities.

The Brazilian installed capacity reached almost $141 \mathrm{GW}$ and the total electricity generation was 581 TWh in 2015 . The net electricity consumption is around $465 \mathrm{TWh}$ and there are 114 companies (private, public and mixed economy) in the distribution sector. The difference between energy generation and consumption indicates that there are around $20 \%$ of total losses (approx. 116.3 TWh) along the power system, including transmission and distribution grids. Its electricity losses level is quite distant from the $9 \%$ average of countries with similar economic situation.
This research focuses on one specific characteristic of the Brazilian power system: the high level of non-technical losses. The Brazilian Regulatory Electricity Agency (ANEEL) divides the losses in distribution in two categories: i) Technical Losses: energy consumed by the distribution infrastructure due to heat loss (Joule effect) in equipment (transformers, cables, etc.); ii) Non-

technical Losses: a value determined by the difference between the total losses and the technical losses. It represents all the other distribution energy losses which are directly associated with the commercial management of the distribution utility, as energy theft, measuring and billing irregularities, unpaid bills, etc.

ANEEL estimates that $5 \%$ of the energy injected to the distribution grids is lost because of fraud and theft, which represents more than 18.3 TWh every year. Considering the average residential electricity consumption in Brazil of $194 \mathrm{kWh} /$ month, this amount could supply 7.9 million households during one year or the entire Center-West region of Brazil for six months. The amount of nontechnical losses varies among distributors and it can reach values above $20 \%$. Socio-economic and cultural characteristics of the population are the main reason for the issue.

It is estimated that the non-technical losses generate a negative impact of more than $\mathrm{R} \$ 4.5$ billion per year (approx. $€ 1.26$ billion). The most recent data available is from February 2017 and the Agency estimates that this category of losses reached $\mathrm{R} \$ 8.15$ billion (approx. $€ 2.3$ billion). 
This study shows the results of different scenarios in which the use of photovoltaic systems could reduce nontechnical losses and its impact on distribution utilities and consumers in Brazil [1].

\section{Interest of the work}

The search for the development of electric energy generation based on renewable resources has deeply transformed the power sector. Among different solutions that are inserted into that context, distributed generation (DG) is one of the elements that has increased fast around the globe and it has the potential of changing the traditional model of power generation that has existed for more than one hundred years.

The definition of DG varies in the literature, but this study considers that it refers to small and medium power plants located at or near electricity end users. They may be connected or not to the utility grid, and include all generation technologies.

The possibility of generating electricity from renewable resources near the consumer may generate various positive impacts. This study approaches the technical and economic benefits that DG may create for low-income citizens. It presents a contribution to evaluate the introduction of DG as a method to reduce non-technical losses.

\section{Objectives}

The objective of this study is the evaluation of the potential economic and technical benefits that distributed generation can create to low-income households. Based on the financial impact of non-technical losses on the Brazilian power system, it aims to propose a pioneer analysis of potential economic and technical benefits that the insertion of DG in low-income communities can create, and alternatives to allow viable financing.

\section{Main contributions}

There are various strategies to reduce the non-technical losses described in the literature. There are also descriptions of methods used in real cases, in different regions of the world, that achieved success or not. This research focuses on energy theft, the main cause of commercial losses, to evaluate the potential benefit of using distributed generation to reduce the damage caused by non-technical losses. Smith [2] identifies three methods to fight power theft:

\section{i. Technical / Engineering}

Innovative solutions and technologies upgrade power system and allow the reduction of commercial losses, including the use of information technology to monitor systems and electronic meters that transmit readings to a remote place and automated meter reading, among many other solutions.

\section{ii. Managerial}

Distribution utilities usually are large and complex companies. Because of that, the bureaucracy may reduce their efficiency and the development of an effective anti-theft program may improve their results. The companies must monitor the consumers frequently to avoid losses and discourage them from stealing energy. Moreover, Distribution Utility (DU) must fight corruption, which is a complex issue that may be present in any sector and level of the utility.

\section{iii. System change}

Systems with a high standard of governance have more chances to have reduced levels of theft. Societies with higher corruption levels and a not competitive power system have lower chances to reduce non-technical losses to reasonable patterns.

The methods and solutions developed to reduce nontechnical losses usually pursue ways to avoid that users consume energy without regularly paying for it. However, the traditional approach has not produced effective results in some regions of Brazil. Areas with a complex socioeconomic situation (areas controlled by criminal groups, high levels of poverty, etc.) have not faced a sustainable reduction of non-technical losses. This research looks for the issue from a different point of view:

\section{What if consumers start generating their own energy instead of stealing it?}

Instead of searching ways to block energy that flows illegally from the distribution grid, government and distributors could point their efforts to transform the illicit consumers into regular prosumers (acronym explained in the next paragraph), reducing non-technical losses, improving the quality of service and contributing to improve socioeconomic situation of low-income communities.

Technological systems that allow local generation of electricity reached a level of development high enough to allow that the acronym prosumer becomes a common term in discussions about distributed generation. In this specific case, prosumer means that the consumer of energy starts to act also as a producer. The prices of some equipment have dropped drastically for the last decade and systems became economically viable in many countries. Brazil`s territory has favorable conditions for solar energy applications. Because of that, the study considers the use of photovoltaic (PV) systems on the rooftops of residences to evaluate the possibility of using DG to reduce commercial losses.

Different scenarios are proposed and simulated to analyze the potential benefit of DG to minimize the impact of non-technical losses. The study is based on the potential photovoltaic generation on rooftops in a specific region of Brazil and on a hypothetical photovoltaic system installed in the same region. The technical and economic analysis is performed to quantify the potential impact and support further discussions about the viability of the proposed solutions. 


\section{Technical Assessment}

The technical assessment begins with the definition of the location that will be the base for the proposed scenarios that are analyzed on topic about the economic assessment. The definition of the area respected some prerequisites in order to narrow the search and to generate reliable results, close to the ones that can be found in the reality of Brazil: urban area, distribution utility with a big number of consumers, high level of non-technical losses, complex socioeconomic situation, low level of reduction of losses along the last 5 years, significant amount of data available for public access.

Based on that scope, the concession area of the company LIGHT (Light Serviços de Eletricidade S/A) was chosen. It comprehends 31 counties of the Rio de Janeiro state, including the metropolitan area of its capital. The distributor supplies electricity to around 4.2 million consumers (approx. 10 million people). The behavior of the losses in the middle of 2016 is detailed in TABLE I, following a division proposed by the company itself and available for public access. The results clarify the relevant difference between "risky areas", where the action of the distributor is limited by a variety of causes related to violence, and the rest of that are called "possible areas".

TABLE I - LOSSES IN RISKY AND POSSIBLE AREAS. ADAPTED FROM LIGHT

\begin{tabular}{llllll}
\hline & $\begin{array}{l}\text { Non- } \\
\text { Technic } \\
\text { Losses } \\
\text { (GWh) }\end{array}$ & $\begin{array}{l}\text { Total } \\
\text { Losses } \\
(\mathbf{G W h})\end{array}$ & $\begin{array}{l}\text { Grid } \\
\text { Load } \\
(\mathbf{G W h})\end{array}$ & $\begin{array}{l}\text { \% Non- } \\
\text { Technic. } \\
\text { Losses / } \\
\text { Grid } \\
\text { Load }\end{array}$ & $\begin{array}{l}\text { \% Total } \\
\text { Losses / } \\
\text { Load }\end{array}$ \\
\hline $\begin{array}{l}\text { Risky } \\
\text { areas }\end{array}$ & 2,793 & 3,094 & 3,771 & $\mathbf{7 4 . 0 6 \%}$ & $82.06 \%$ \\
\hline $\begin{array}{l}\text { Possible } \\
\text { areas }\end{array}$ & 3,422 & 5,933 & 33,974 & $\mathbf{1 0 . 0 7 \%}$ & $17.46 \%$ \\
\hline Total & 6,214 & 9,028 & 37,744 & $\mathbf{1 6 . 4 6 \%}$ & $23.92 \%$ \\
\hline
\end{tabular}

The company divides its concession area into five different groups to present the results of the losses: Vale do Paraíba, Baixada, Oeste, Leste, and Centro-Sul. Based on that division, it is possible to compare the behavior of the losses between counties with different socioeconomic characteristics and highlight the regions with the higher losses in TABLE II.

TABLE II - LOSSES IN THE CONCESSION AREA DIVIDED INTO 5 MAIN REGIONS. ADAPTED FROM LIGHT.

\begin{tabular}{|c|c|c|c|c|c|c|}
\hline & Total & $\begin{array}{l}\text { Vale do } \\
\text { Paraíba }\end{array}$ & $\begin{array}{l}\text { Centro- } \\
\text { Sul }\end{array}$ & Leste & Oeste & $\begin{array}{l}\text { Baixa } \\
\text { da }\end{array}$ \\
\hline $\begin{array}{l}\text { N. of } \\
\text { consumers } \\
(x 1,000)\end{array}$ & 4,271 & 443 & 849 & 884 & 1,013 & 1,083 \\
\hline $\begin{array}{l}\text { Invoice } \\
\mathrm{LV} \\
(\mathrm{GWh})\end{array}$ & 14,515 & 1,262 & 5,094 & 2,724 & 2,798 & 2,637 \\
\hline $\begin{array}{l}\text { Non- } \\
\text { Technical } \\
\text { Losses } \\
\text { (GWh) }\end{array}$ & 5,753 & 11 & 75 & 1,837 & 1,895 & 1,935 \\
\hline $\begin{array}{l}\text { Non- } \\
\text { Technical } \\
\text { Losses / } \\
\text { Invoiced } \\
\text { LV (\%) }\end{array}$ & 39.63 & 0.9 & 1.5 & 67.4 & 67.7 & 73.4 \\
\hline
\end{tabular}

After defining the area of Brazil to be studied, it was necessary to narrow the search even more and the city of Belford Roxo was chosen for the sizing of the PV project. The city has the third highest level of energy theft in its concession area and a population of almost 470,000 people.

In order to estimate the potential amount of electricity that can be generated by systems installed on the roof of residences in Belford Roxo, this document considers the results of a study developed to GIZ, a German provider of international cooperation services [3], for the state of Rio de Janeiro (RJ). The research estimates the value of the total usable irradiation on residential roofs in Brazil without including the efficiency of the PV system. This document analyzes the results only for the State of Rio Janeiro (RJ) to subsidize further calculations and approximations to the city of Belford Roxo.

The mentioned research also develops four different scenarios to estimate the generation on roofs. It is important to highlight that the scenarios presented by LANGE [3] are NOT the same of those that are detailed and analyzed in this article about the reduction of nontechnical losses. The total irradiation that can be used to PV generation varies from $537 \mathrm{GWh}$ /day until 2,018 $\mathrm{GWh}$ /day in RJ. Based on the results for the whole state, it is developed the estimation of the potential electricity generation from roof PV systems in the city of Belford Roxo.

The total amount of electricity that can be generated, considering conservative and optimist scenarios in Belford Roxo, varies from 572.60 GWh until 1,992.66 GWh per year, respectively. The real average residential consumption for Belford Roxo is not available, so this study assumes the same value of the Southwest Region: $243 \mathrm{kWh} /$ month per residence. The yearly consumption in the whole city is estimated at $424.77 \mathrm{GWh} /$ year and the potential generation by PV systems could cover all the supply reliably.

The solar potential and load consumption are already known. The next step is to define a hypothetical system that can cover the consumption of one residence for the whole year. The main objective of this study is to evaluate the potential of distributed generation to reduce power losses in low-income communities, transforming irregular consumers into generators and properly finance that initiative. The scope does not include the evaluation of the economic viability of DG in comparison to other types of investments. Instead of that, the economic assessment analyzes the viability to implement the solution in low-income areas while contributing to the reduction of non-technical losses. The current legislation of Brazil allows "Net Metering", so the credits accumulated along the year compensate the months with higher consumptions. Because of that, the chosen PV system is enough to cover at least the average consumption of the whole year.

After looking for options in the market, it was selected a system with $2.56 \mathrm{~kW}_{\mathrm{p}}$ of nominal power and compound 
by 8 panels of SOLAR CANADIAN CS6X-320P - 72 Cells - 320W and inverter FRONIUS GALVO 2.5.1 - 2.5 $\mathrm{kW}$ inverter and SOLAR CANADIAN CS6X-320P - 72 Cells - 320W $\left(15 \mathrm{~m}^{2}\right)$. The individual investment considers that the system costs $€ 3,803$, the installation requires $€$ 833 and the maintenance during 25 years will cost $€ 1,111$.

\section{Economic Assessment}

At this point of the study, scenarios are proposed to estimate the potential reduction in commercial losses that distributed generation can permit if massively introduced in areas in which the current solutions are not effective. Different scenarios are presented to quantify the economic benefits, assuming that the systems are installed for consumers that currently steal energy. Moreover, the analysis includes the investment that is necessary to implement the systems.

In the case of Belford Roxo, the hypotheses of six scenarios generate different economic benefits by the reduction of losses that impact on the tariffs and require different investment volumes, which are summarized in TABLE III.

TABLE III - POTENTIAL BENEFITS FOR DIVERSE SCENARIOS OF DG AND COST OF IMPLEMENTATION - BELFORD ROXO

\begin{tabular}{|c|c|c|c|c|c|c|}
\hline \multicolumn{7}{|c|}{ SCENARIOS } \\
\hline & $\begin{array}{l}100 \% \\
\text { reduction }\end{array}$ & $\begin{array}{l}75 \% \\
\text { reduction }\end{array}$ & $\begin{array}{l}50 \% \\
\text { reduction }\end{array}$ & $\begin{array}{l}20 \% \\
\text { reduction }\end{array}$ & $\begin{array}{l}\text { "Leste" } \\
\text { Region } \\
\text { Limit }\end{array}$ & $\begin{array}{l}\text { Regulatory } \\
\text { Limit }\end{array}$ \\
\hline $\begin{array}{l}\text { Non- } \\
\text { Technical } \\
\text { Losses LV } \\
\text { Reduction } \\
\text { (GWh) }\end{array}$ & 311.778 & 233.833 & 156 & 62.356 & 25.486 & 158.607 \\
\hline $\begin{array}{l}\text { Economic } \\
\text { Benefit per } \\
\text { year } \\
(x \in 1,000)\end{array}$ & 45,641 & 34,231 & 22,820 & 9,128 & 3,731 & 23,218 \\
\hline $\begin{array}{l}25 \text { years of } \\
\text { Economic } \\
\text { Benefit } \\
(x \in 1,000)\end{array}$ & $1,141,019$ & 855,764 & 570,510 & 228,204 & 93,271 & 580,458 \\
\hline $\begin{array}{l}\text { Number of } \\
\text { Required } \\
\text { Systems }\end{array}$ & 106,920 & 80,190 & 53,460 & 21,384 & 8,740 & 54,392 \\
\hline $\begin{array}{l}\text { Total } \\
\text { Installation } \\
\text { Cost } \\
(x \in 1,000)\end{array}$ & 346,984 & 278,826 & 185,884 & 79,311 & 34,442 & 189,126 \\
\hline $\begin{array}{l}\text { Total Cost } \\
\text { in } 25 \text { years } \\
(x \in 1,000)\end{array}$ & 465,783 & 367,926 & 245,284 & 103,070 & 44,153 & 249,561 \\
\hline
\end{tabular}

The "Leste" Region Limit scenario estimates the necessary expansion in distributed generation based on PV systems to reduce the losses in Belford Roxo ("Baixada" region) to the level of "Leste" region: 67,4\%. The last scenario estimates the amount of systems and investment that is necessary to improve the efficiency of the supply to reach the regulatory level determined by ANEEL for the area of the state of Rio de Janeiro attended by LIGHT, 36.06\%. The economic benefit represents the commercial losses that are avoided, considering the average energy tariff of $€$ $0.146 / \mathrm{kWh}$.

The next step is to extrapolate the analysis to the whole concession area of LIGHT in different scenarios detailed in TABLE IV. In this case, the focus of the economic benefit are the locations in which the actions of the DU are limited by the risk. The technical teams are not able to enter these locations without the support of the state, even with police reinforcement. The introduction of DG would be developed in risky areas not only to reduce losses, but also to benefit the population with less favorable socioeconomic level. This study considers that the reduction of non-technical losses in the rest of the locations can continue by the use of other methodologies already developed. The use of DG can be evaluated in a second moment depending on the results achieved in risky areas.

TABLE IV - POTENTIAL BENEFITS FOR DIVERSE SCENARIOS OF DG AND COST OF IMPLEMENTATION - CONCESSION AREA

\begin{tabular}{|c|c|c|c|c|c|c|}
\hline \multicolumn{7}{|c|}{ SCENARIOS } \\
\hline & $\begin{array}{l}100 \% \\
\text { reduction }\end{array}$ & $\begin{array}{l}75 \% \\
\text { reduction }\end{array}$ & $\begin{array}{l}50 \% \\
\text { reduction }\end{array}$ & $\begin{array}{l}20 \% \\
\text { reduction }\end{array}$ & $\begin{array}{l}\text { "Leste" } \\
\text { Region } \\
\text { Limit }\end{array}$ & $\begin{array}{l}\text { Regulatory } \\
\text { Limit }\end{array}$ \\
\hline $\begin{array}{l}\text { Non- } \\
\text { Technical } \\
\text { Losses LV } \\
\text { Reduction } \\
\text { (GWh) }\end{array}$ & $2,585.795$ & $1,292.897$ & 517.159 & 258.579 & 129.290 & 232.908 \\
\hline $\begin{array}{l}25 \text { years of } \\
\text { Economic } \\
\text { Benefit } \\
(x \in 1,000)\end{array}$ & $9,463,291$ & $4,731,645$ & $1,892,658$ & 946,329 & 473,165 & 852,380 \\
\hline $\begin{array}{l}\text { Number of } \\
\text { Required } \\
\text { Systems }\end{array}$ & 886,761 & 443,380 & 177,352 & 88,676 & 44,338 & 79,873 \\
\hline $\begin{array}{l}\text { Total } \\
\text { Installation } \\
\text { Cost } \\
(x \in 1,000)\end{array}$ & $2,672,229$ & $1,438,893$ & 575,557 & 308,334 & 154,167 & 277,723 \\
\hline $\begin{array}{l}\text { Total Cost } \\
\text { in } 25 \text { years } \\
(x \in 1,000)\end{array}$ & $3,657,519$ & $1,931,538$ & 772,615 & 406,863 & 203,432 & 366,471 \\
\hline
\end{tabular}

\section{Financing}

The insertion of distributed generation based on PV systems installed on the roof of houses and apartments requires a large initial investment, which makes it one of the main barriers for the development of such generation solution. Although the benefits may be clear after a viability analysis, especially in regions with high solar incidence, the amount of money that is required to start generating electricity is not available for many homeowners. Because of that, the availability of financing options is required to promote the massive growth of distributed generation, especially in the case of low-income citizens.

This research evaluates different hypotheses to simulate the participation of consumers, government and distributors to finance the insertion of DG. In the case of areas with high non-technical losses, the benefits of DG reach all the three mentioned stakeholders directly.

The Normative Resolution 482/2012, revised by the Normative Resolution 687/2015, published by ANEEL, defines the current regulation about distributed generation in Brazil [4]. It establishes the conditions for distributed generation of electricity from renewable sources, or qualified cogeneration, and a system of electrical energy compensation (net metering). It defines distributed microgeneration for systems until $75 \mathrm{~kW}$ of 
installed capacity and mini generation for those between $75 \mathrm{~kW}$ and $5 \mathrm{MW}$ (3MW for hydraulic sources), connected to the distribution grid through the consumers.

The energy that is generated, but not consumed in a specific month, becomes a credit that can be used as supply in the following months. The credits last 60 months ( 5 years) and they can be also used to reduce the electricity bill of different units of the same owner, but only inside the region supplied by the same DU. Multiple consumers in the same condominium can also generate energy as a group and define how the electricity is divided. Moreover, the regulation authorizes the many consumers associated in a collective to install one plant of micro or mini generation and reduce the electricity bills of the members of the association.

The financing simulations consider the current regulation just mentioned and different possibilities to reduce the impact for low-income consumers. The results presented in TABLE V support the discussion about the alternative that may turn the investment in PV systems viability in these communities. It is assumed that the consumers do not have any value to spend initially and the financing covers $100 \%$ of the value of the system. The simulations consider a single system supported by one consumer and equated monthly installments (equal payments) [1].

TABLE V - SimULATIONS ABOUT FINANCING

\begin{tabular}{lll}
\hline Conditions & $\begin{array}{l}\text { Loan length } \\
\text { (years) }\end{array}$ & $\begin{array}{l}\text { Monthly } \\
\text { Installments }\end{array}$ \\
\hline Retail price + Current interest & 5 & $€ 117.73$ \\
\hline Retail price + Small business interest “A" & 10 & $€ 66.73$ \\
\hline Retail price + Small business interest "B" & 20 & $€ 39.75$ \\
\hline Retail + Reduced interest & 25 & $€ 38.14$ \\
$\begin{array}{l}\text { Retail price + Current interest rate + DU } \\
\text { investment }\end{array}$ & 25 & $€ 36.68$ \\
$\begin{array}{l}\text { Retail price + Reduced interest rate + DU } \\
\text { investment }\end{array}$ & 25 & $€ 34.33$ \\
$\begin{array}{l}\text { Wholesale price + Current interest rate } \\
\text { Wholesale price + Reduced interest rate }\end{array}$ & 25 & $€ 34.18$ \\
$\begin{array}{l}\text { Wholesale price + Current interest + DU } \\
\text { investment }\end{array}$ & 25 & $€ 31.99$ \\
$\begin{array}{l}\text { Wholesale price + Reduced interest + DU } \\
\text { investment }\end{array}$ & 25 & $€ 31.55$ \\
$\begin{array}{l}\text { Cheaper wholesale price + Inflation+ DU } \\
\text { investment }\end{array}$ & 25 & $€ 29.53$ \\
\hline
\end{tabular}

\section{Discussion}

The objective of this article is to present some arguments to support the reader's understanding of the potential benefits of the proposed solution and the aspects that may turn projects viable.

As detailed in the proposed scenarios, different levels of insertion implicate in higher or smaller levels of reduction of commercial losses, but the economic benefit in all the proposed scenarios is more than 2 times bigger than the cost to implement the distributed generation.

Besides that, if the insertion of DG in areas with high commercial losses focuses on irregular consumers, each user that becomes a prosumer stops impacting on the energy tariff. The perverse effect of regular consumers that subsidize illegal energy supply is immediately reduced, independently of the number of PV systems installed. This fact may also reduce the price of energy for all the consumers in a specific concession area. The inclusion of prosumers has long-term effect on the distribution system because the PV systems can generate electricity for 25 years with considerable reliability and do not use to need much maintenance.

The distributors may also reduce their financial losses if the current non-technical losses are above the regulatory limit imposed by ANEEL. In that case, the amount of energy over the limit is paid by the DU and directly affects its results. Moreover, the reduction of nontechnical losses can reduce the necessity of interventions and investment in the grid caused by illegal connections.

Fig. 1 shows in green the available data about nontechnical losses in the concession area of LIGHT. The lines of the graph beginning in June 2015 are rough projections of non-technical losses reduction depending on the total amount invested in purchasing and installing PV systems in consumers that currently are illegal consumers in risky areas of Rio de Janeiro. They consider that the total amount of consumption and commercial losses do not increase over the years. Each line projects values of non-technical losses that could be reached if the investments are repeated every year until June 2021. The level of commercial losses would vary from $18.26 \%$ to $34.29 \%$ in the end of the projected period.

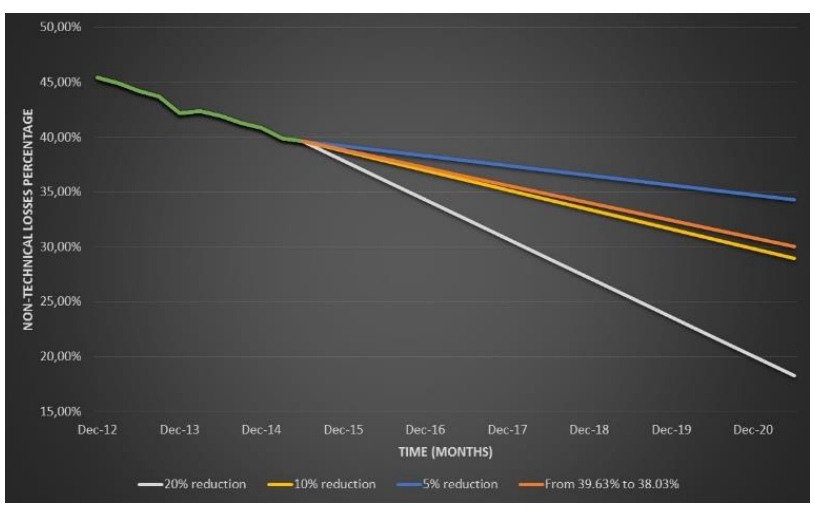

Fig. 1 - Projection on non-technical losses reduction depending on scenarios

The results show that distributed generation may be considered an alternative to reduce non-technical losses, especially in areas where other methods are not effective. The insertion of DG can generate benefits that are much bigger than the initial investment in the long term. Besides that, if an irregular consumer becomes a "prosumer" it is likely that he or she would not connect irregularly again, at least during the period that the PV system is supplying all his or her needs.

The traditional methods usually applied to avoid irregular consumption are focused on avoiding the theft of energy. They may be effective in many situations, but lowincome citizens are highly sensitive to the socioeconomic changes. If family earnings are reduced because of an 
economic crisis or unemployment, for example, the irregular connections may raise again in areas where existing methods for reduction commercial losses were already applied. In the case of distributed generation, in theory, even if the families stop paying the loan used to buy the PV systems, the energy used by them keeps being generated and the DU does not need to buy energy from another generator to supply them (this fact needs a legal analysis that is not considered by this research).

The risky areas are a challenge for the operation teams of distributor companies and for the combat energy theft. It is a highly complex social issue for the Brazilian society, the support of governmental institutions, including law enforcement, is essential, and it would be necessary also to make the insertion of DG possible. However, the installation of PV systems has some characteristics that may increase the acceptance by the population. The creation of prosumers give the users a new role in the power system and may turn the citizens aware of the contribution that PV systems generate to the communities. The communities could even organize cooperatives to promote the efficiency division of the energy among the members. If the impact of the systems in the families' budget is smaller than the energy bill and other potential benefits are clear to the consumers, the acceptance can be higher than other methods that aim to avoid theft.

Technical and managerial methods can be seen by the population just as ways to make disconnection easier without any direct benefit for the consumers. It is reasonable to look for a market in which everyone consumes energy legally. Social campaigns have helped to show that energy theft is a crime in Brazil and illegal connections cause damage. Despite of all the effort already done using the traditional methods, even if they include new technological solutions, the non-technical losses are still quite high in certain locations of Brazil. It requires continuous efforts from companies and the Government in order to tackle the problem. LIGHT itself has made significant progress in certain locations to reduce nontechnical losses, with initiatives like the "Área Perda Zero (APZ)" (Zero-Loss Area) that focus on areas with high indexes of theft and defaults, but the total commercial losses keep being significant.

DG based on PV also reduce greenhouse-gas (GHG) emissions. Depending on the scenario, the insertion of DG in Belford Roxo could avoid emissions between 2,031.72 and $24,854.71$ tons of $\mathrm{CO} 2 \mathrm{eq}$ per year. In the case of the risky areas, the values vary from 10,306.90 and 206,137.98 tons of CO2eq per year.

The initial investment to install many PV systems may become a barrier because it requires a huge amount of money. Considering that, loans are required to make feasible that consumers and distributors invest in DG. The simulations exemplify optimist results for financing the systems for low-income consumers which depend on factors that are far from the current conditions available in the Brazilian market. However, it shows that there are various possibilities that can reduce the cost of PV systems to low-income consumers.

\section{Conclusion}

This work has proposed a method to reduce the nontechnical losses by the insertion of DG in low-income communities, which can provide economic and technical benefits. It includes a discussion about conditions regarding projects financing.

The developed case study shows that the financial impact of non-technical losses in Brazil is relevant. Moreover, it indicates that the distributed generation could be considered an alternative solution to reduce these losses and generate technical and economic benefits in lowincome communities. It may also reduce greenhouse-gas (GHG) emissions.

The introduction of DG in areas with high levels of commercial losses can be a more effective way of reducing losses than the traditional methods. The current illegal users can be transformed in "prosumers" and reduce the electricity bills for the regular consumers and distributors that currently subsidize the illegal supply. The quality of the supply may improve and reduce the maintenance costs of the distribution utilities. If number of illegal connections is reduced, the frequency and the duration of supply interruptions can be reduced.

The massive insertion of DG to reduce commercial losses in low-income communities, including risky areas, depends on loans that are affordable to that population. Government, distributors and society should work together in integrated actions to the make the proposed solution feasible.

\section{Acknowledgement}

This work was supported by the Brazilian Ministry of Transparency and Comptroller-General (CGU). Additionally, the authors wish to thank the Electronic Engineering Department and the Electrical Engineering Department of the Polytechnic University of Catalonia (UPC) for the support that it has given us over all these years.

\section{References}

[1] E. Baffi, "Contributions to evaluate technical and economic benefits of distributed generation for low-income citizens, " Master Thesis, 2017.

[2] T. B. Smith, "Electricity theft: A comparative analysis," Energy Policy, vol. 32, no. 18, pp. 20672076, 2004.

[3] W. J. Lange, "Metodologia de mapeamento da área potencial de telhados de edificações residenciais no Brasil para fins de aproveitamento energético fotovoltaico," 2012.

[4] ANEEL - Agência Nacional de Energia Elétrica, "Resolução Normativa ANEEL 482/2012." 2012. 